\title{
Peran Komunikasi, Informasi, dan Edukasi pada Asma Anak
}

\author{
M. Arif Matondang, Helmi M Lubis, Ridwan M Daulay, G Panggabean, Wisman Dalimunthe \\ Departemen Ilmu Kesehatan Anak, FK-USU/RS H. Adam Malik, Medan
}

\begin{abstract}
Asma merupakan penyakit inflamasi kronik, kadangkala memerlukan tata laksana jangka panjang. Program komunikasi, informasi, dan edukasi (KIE) merupakan bagian tata laksana asma. Dengan penerapan program KIE diharap dapat mengurangi kekambuhan asma, meningkatkan pengetahuan, mengurangi biaya pengobatan dan meningkatkan kualitas hidup. Dibutuhkan kerjasama unsur terkait pada tata laksana asma. (Sari Pediatri 2009;10(5):314-9).
\end{abstract}

Kata kunci: asma, KIE

A sma merupakan penyakit respiratorik kronik yang sering ditemukan, baik di negara maju maupun di negara berkembang. Penyakit asma pada umumnya dimulai sejak masa kanak-kanak. Asma menimbulkan dampak negatif pada kehidupan pasien, menyebabkan anak sering tidak masuk sekolah dan membatasi kegiatan aktivitas pribadi maupun keluarga. Dilaporkan sejak dua dekade terakhir prevalensi asma meningkat. Prevalensi asma sangat bervariasi, berbeda antar negara bahkan antar daerah di suatu negara. ${ }^{1,2}$ Prevalensi asma di dunia diperkirakan 7,2\% (10\%

\footnotetext{
Alamat Korespondensi:

dr. Muhammad Arif Matondang. Departemen Ilmu Kesehatan Anak FK-USU/RSUP H. Adam Malik Medan Jl. Bunga Lau No. 17, Medan 20136, PO Box 697. Telepon : 061-8360405, 8360142. Fax. 061-8361721 E-mail:bikafkusu@telkom.net,arifmatondang@yahoo.com
}

pada anak dan 6\% pada dewasa). Prevalensi asma di Indonesia tahun 2002, dilaporkan oleh Kartasasmita di Bandung dari 2678 anak, kelompok usia 6-7 tahun 3,0\%, dan dari 2836 anak kelompok usia 13-14 tahun 5,2\%. Rahajoe di Jakarta melaporkan kelompok usia 13-14 tahun sebanyak 1296 orang didapati prevalensi $6,7 \% .^{1,3}$

Tata laksana asma anak terdiri dari farmaka dan non farmaka, KIE merupakan salah satu tata laksana non farmaka. Secara umum program KIE merupakan rangkaian kegiatan sistematis, terencana dan terarah. Peran serta aktif pasien, keluarga, dokter dan pihak sekolah sangat diharapkan, dilaksanakan secara menyeluruh untuk mengatasi masalah asma. Pada pengendalian asma harus diperhitungkan faktor-faktor sosioekonomi, budaya, individu, dan keluarga. ${ }^{2}$

Penjelasan edukasi mencakup serangan asma, gejala alergi dan khususnya keadaaan anafilaksis. Untuk itu, dokter perlu meluangkan waktu melaksanakan KIE kepada orangtua. ${ }^{1,3,4}$ 


\section{Asma pada anak}

Pedoman Nasional Asma Anak menggunakan defenisi praktis operasional untuk asma anak. Asma mengi dan/ atau batuk, timbul secara episodik dan/atau kronik, cenderung terjadi pada malam/dini hari (nokturnal), dan musiman. Adanya faktor pencetus di antaranya aktifitas fisik, bersifat reversibel baik secara spontan maupun dengan pengobatan, serta adanya riwayat asma atau atopi lain pada pasien/keluarga. Namun penyebab lain telah disingkirkan. ${ }^{3}$

Konsep terkini mengenai patogenesis asma adalah suatu proses inflamasi kronik spesifik, melibatkan dinding saluran respiratorik, menyebabkan aliran udara terbatas dan peningkatan reaktivitas saluran nafas. Hipereaktivitas merupakan predisposisi terjadinya penyempitan saluran respiratorik sebagai respon terhadap berbagai macam rangsangan. Gambaran inflamasi spesifik berupa aktivitas eosinofil, sel mast, makrofag dan sel limfosit $\mathrm{T}$ pada mukosa dan lumen saluran respiratorik. Perubahan tersebut dapat terjadi meskipun asma tidak bergejala. Terjadinya kerusakan sel tersebut secara luas berhubungan dengan derajat penyakit. Sejalan dengan proses inflamasi kronik, lepasnya epitel bronkus merangsang proses reparasi saluran respiratorik menghasilkan perubahan struktural dan fungsional yang menyimpang pada saluran respiratorik. Penyimpangan tersebut dikenal dengan istilah remodeling, merupakan serangkaian proses penyebab deposisi jaringan penyambung dan mengubah struktur saluran respiratorik melalui proses dediferensiasi, migrasi, diferensiasi dan maturasi struktur sel. ${ }^{1,7,8}$

Wheezing dan/atau batuk kronik berulang merupakan titik awal untuk menegakkan diagnosis asma. Termasuk yang perlu dipertimbangkan kemungkinan asma adalah anak-anak yang hanya menunjukkan batuk sebagai satu-satunya tanda klinis, dan pada saat diperiksa tanda wheezing, sesak, dan lain-lain sedang tidak timbul. Sehubungan dengan kesulitan mendiagnosis asma pada anak kecil khususnya anak di bawah 3 tahun, respon yang baik terhadap obat bronkodilator dan steroid sistemik selama 5 hari dan menyingkirkan penyakit lain, diagnosis asma menjadi lebih defenitif. Untuk anak yang sudah besar ( $>$ 5tahun) pemeriksaan faal paru sebaiknya dilakukan. Uji fungsi paru sederhana dengan peak flow meter, atau yang lebih lengkap dengan spirometri. Uji provokasi bronkus dengan histamin, metakolin, latihan, udara kering dan dingin atau dengan $\mathrm{NaCl}$ hipertonis, sangat menunjang di- agnosis. Selain itu perlu diperiksa foto radiologi paru atau mungkin foto rontgen sinus paranasalis, uji keringat, uji imunologis, uji defisiensi imun, pemeriksaan refluks, uji mukosilier bahkan bronkoskopi serta uji tuberkulin. Berdasarkan alur diagnosis, dapat ditegakkan diagnosis asma, asma dengan penyakit lain, atau bukan asma. Derajat asma dibagi menjadi tiga yaitu asma episodik jarang, asma episodik sering, dan asma persisten. ${ }^{1,3,7,8}$

Manajemen asma meliputi obat-obatan, kontrol lingkungan dan mengenali gejala asma. Pengobatan asma terdiri dari dua kelompok besar, yaitu pereda (reliever) dan pengendali (controller). Obat pereda bertujuan untuk mencapai remisi. Yang termasuk dalam kelompok ini adalah golongan $ß 2$-agonis kerja pendek (short acting beta agonist $=\mathrm{SABA}$ ) dan golongan santin. Obat kelompok ini digunakan untuk meredakan serangan atau gejala asma jika sedang timbul. Bila serangan teratasi dan sudah tidak ada gejala lagi maka obat ini tidak digunakan. Kelompok kedua adalah obat pengendali, bertujuan untuk mempertahankan remisi. Termasuk dalam kelompok obat pengendali adalah golongan antiinflamasi non-steroid, anti-inflamasi steroid, $\beta$-agonis kerja panjang (long acting beta agonist=LABA), obat lepas lambat/lepas terkendali, antileukotrin, dan kombinasi steroid dengan LABA. Obat pengendali digunakan untuk mengatasi masalah dasar asma yaitu inflamasi kronik. Dengan demikian pemakaian obat ini terus menerus dalam jangka waktu yang relatif lama, tergantung derajat penyakit asma dan responnya terhadap pengobatan/penanggulangan. Obat-obat pengendali diberikan pada asma episodik sering dan asma persisten. ${ }^{1,4,7}$

Obat asma dapat diberikan secara parenteral, peroral atau perinhalasi. Perinhalasi adalah pemberian obat secara langsung ke dalam saluran nafas melalui hirupan. Pemberian perinhalasi dapat mengurangi efek samping berupa gangguan gastrointestinal dan lainlain. Pada orang dewasa pemberian perinhalasi banyak digunakan dan berhasil baik. Ada beberapa hal yang perlu diperhatikan pada anak dengan memperhatikan anatomi, fisiologi dan sistem kordinasi. Jenis terapi inhalasi yaitu metered dose inhaler (MDI), MDI dengan spacer, dry powder inhaler (DPI) dan nebulizer. Dibutuhkan keterampilan dalam penggunaan obat inhalasi. ${ }^{1,4,9,10}$ Apabila tata laksana asma jangka panjang gagal atau adanya pajanan dengan pencetus maka diperlukan tata laksana serangan asma. ${ }^{1}$ 


\section{Program KIE pada anak/pribadi}

Program KIE asma anak telah dikembangkan untuk memperbaiki praktek kesehatan, menekan morbiditas, dan mengurangi biaya pengobatan. Banyak penelitian dilakukan mengenai program KIE. Program yang terancang berupa informasi dan keterampilan diterapkan oleh dokter dan tenaga medis yang kompeten. Program KIE telah dievaluasi dan berhasil memperbaiki manajemen asma anak. ${ }^{2,5}$ Lahdensuo $\mathrm{dkk}^{11}$ melaporkan, manajemen pada anak/pribadi dapat menurunkan serangan asma dan meningkatkan kualitas hidup. D'Souza $\mathrm{dkk}^{12}$ melakukan program KIE pada anak selama 6 tahun terhadap 69 anak asma dapat menekan morbiditas. Schermer $\mathrm{dkk}^{13}$ mendapatkan, panduan KIE pada anak merupakan pendekatan alternatif yang aman dan efisien dibanding berobat ke klinik.

Pengetahuan pasien dan keluarga tentang asma mengenai pemakaian obat, kontrol lingkungan dan mengenal gejala asma merupakan bagian penting pada tata laksana asma. ${ }^{7}$ Pada prinsipnya tenaga kesehatan melakukan edukasi dimulai dari pesan-pesan penting setelah mendapat persetujuan pasien. Selalu bersikap ramah dan menenteramkan hati. Tunjukkan perhatian penuh seperti kontak mata dan mendengarkan secara baik. Berikan dorongan komunikasi nonverbal seperti mengangguk, tersenyum dan lain-lain. Berikan pujian dalam strategi manajemen yang efektif dan gunakan bahasa interaktif. Bangkitkan pengetahuan pasien tentang asma dan hilangkan rasa takut dengan informasi yang menenteramkan. Setiap melakukan KIE senantiasa mengingatkan aturan pakai obat, keterampilan penggunaan obat semprot dan pemakaian peak flow meter (PFM), pengawasan lingkungan dan penetapan langkah-langkah pengobatan sewaktu serangan. ${ }^{4,9}$

Panduan program KIE pada anak dalam mencegah, menilai dan mengobati gejala asma merupakan kunci keberhasilan untuk mengontrol asma. Panduan tersebut adalah, ${ }^{4,14,15}$

1. Komunikasi antara pasien dan dokter untuk mengetahui keluhan pasien

2. Pengertian tentang kenyataan yang mendasar, penyebab, dan pencetus asma

3. Mengidentifikasi dan mengontrol faktor-faktor yang memperburuk gejala asma dan pencetus serangan

4. Mengikuti rencana aksi tertulis untuk menghindari atau menangani saat serangan
5. Pengertian tentang pentingnya penggunaan obat yang tepat dan benar dari spacer dan inhaler untuk kontrol jangka panjang

6. Monitor gejala dan nilai peak flow pada asma persisten dan memperbaiki pengobatan sesuai

7. Informasi untuk menurunkan ketergantungan pengobatan yang tidak terbukti.

Program KIE dimulai saat pertama kali diagnosis ditegakkan dan terintegrasi ke dalam setiap langkah penanganan asma, diberikan oleh semua anggota tim kesehatan. Diberikan pertanyaan untuk dapat menilai keadaan penyakit dan diberikan informasi dan keterampilan tentang asma pada setiap kali kesempatan. Selain kepada pasien edukasi diberikan juga kepada orang-orang yang terlibat seperti dokter, perawat, petugas rumah sakit lainnya, keluarga, kelompok bermain, guru sekolah, dan seluruh masyarakat umumnya.,

\section{Program KIE pada keluarga/di rumah}

Program KIE pribadi diterapkan pada asma anak yang memerlukan pengobatan jangka panjang. Program dibuat dalam bentuk Rencana Aksi Asma (RAA), Asthma Action Plan (AAP), rencana dibuat secara tertulis dan diisi oleh orang tua. Rencana ini bertujuan, ${ }^{4}$

- Membebaskan dari gejala asma berat siang dan malam termasuk gangguan tidur malam

- Meningkatkan fungsi paru terbaik yang mungkin dimiliki

- Mampu berpartisipasi penuh dalam aktivitas yang dipilih

- Mengurangi absen masuk sekolah oleh karena gejala asma

- Tidak membutuhkan tindakan darurat atau perawatan rumah sakit terhadap serangan asma

- Penggunaan obat untuk pengendali asma dengan sedikit efek samping.

Untuk melaksanakan RAA, dokter memberikan catatan harian asma diisi oleh orang tua setiap hari untuk memonitor keadaaan tidur malam, gejala asma, aktivitas, reak, peak flow rate (PFR), pemakaian obat harian, dan penggunaan inhaler. ${ }^{1,4,8}$ Guendelman $\mathrm{dkk}^{16}$ melaporkan penggunaan catatan asma, monitoring gejala asma dan status fungsional dengan menggunakan suatu program dapat meningkatkan keterampilan manajemen pribadi dan meningkatkan diagnosis asma. 
Pemantauan harian mempergunakan tiga zona warna untuk membantu pengobatan asma. Warna hijau mengisyaratkan tetap menggunakan obat pencegah asma. Warna kuning mengisyaratkan penggunaan obat pereda (short acting bronchodilator) sebagai tambahan obat. Warna merah berarti segera ke dokter. Masing-masing warna tersebut memiliki kriteria untuk PFR dan gejala serta rencana aksi masing-masing warna tersebut. Penggunaan $P F M$ di rumah dapat dilakukan pada anak usia di atas 5 tahun dengan mengikuti panduan yang telah ditetapkan. ${ }^{4}$

Untuk menggunakan PFM anak harus berdiri dengan indikator mengarah ke bawah, kemudian anak mengambil nafas dalam dan meniup dengan kuat dan cepat hingga indikator penunjuk bergerak pada skala. Nilai yang diambil adalah nilai peak expiratory flow rate (PEFR)/arus puncak ekspirasi (APE) tertinggi yang diperoleh setelah tiga kali berturut-turut diulang. Pada anak nilai terbaik adalah nilai APE tertinggi yang dicapai setelah dua minggu dalam keadaan stabil. Rencana tertulis dibuat berdasarkan nilai anak yang terbaik. Adanya tiga zona APE, yaitu zona hijau menunjukkan $80-100 \%$ dari nilai terbaik anak, pada zona ini gejala asimtomatik. Zona kuning menunjukkan APE $50-80 \%$, gejala sudah tampak. Sedangkan zona merah menunjukkan APE $<50 \%$, merupakan keadaan gawat darurat dan harus segera menghubungi dokter atau rumah sakit. ${ }^{4,6}$ Wensley $\mathrm{dkk}^{17}$ dalam suatu penelitian melaporkan, penggunaan PFM membuat pengobatan berlebihan, sebaiknya penentuan pengobatan berdasarkan gejala, fungsi paru, inflamasi jalan napas, respon bronkus, dan remodeling jangka panjang.

\section{Program KIE di sekolah}

Kontrol lingkungan sekolah juga diperlukan. Program KIE pada orang tua, guru, teman dan petugas sekolah dibutuhkan untuk menyediakan lingkungan yang aman untuk anak yang berisiko anafilaktik terhadap makanan dan gigitan serangga. Keseluruhan terwujud dengan membuat lingkungan bebas makanan alergi dan identifikasi supervisor untuk dihubungi melalui telepon saat keadaan darurat. ${ }^{14}$ Pengawasan lingkungan harus diterapkan untuk mencegah paparan udara sekitar atau kontak alergi. ${ }^{14}$ Program KIE sekolah diterapkan dalam bentuk Kartu Aksi Asma Siswa (KAAS) berisi identitas anak dan nomor telepon untuk dapat dihubungi bila terjadi kekambuhan, rencana manajemen asma harian dan rencana saat darurat., ${ }^{4,9}$
Rencana manajemen harian berisi, ${ }^{4}$

- Identifikasi faktor pencetus asma seperti aktivitas, infeksi, makanan, debu dan lain-lain

- Kontrol lingkungan sekolah

- Monitor PFR

- Rencana pengobatan harian.

Rencana darurat diperlukan apabila timbul gejala atau nilai peak flow rate menurun. Langkah-langkah tindakan pada episode serangan asma :

1. Berikan pengobatan mengikuti petunjuk yang tercatat di kartu

2. Siswa tetap sekolah jika keadaan anak dapat dikendalikan

3. Hubungi orang tua jika anak tidak bisa mengikuti pelajaran

4. Meminta perawatan medis darurat jika tidak ada perbaikan klinis selama 15-20 menit setelah pengobatan, nilai PFR rendah, sulit bernafas, gangguan berjalan atau bicara dan tidak dapat beraktivitas kembali, serta bibir atau kuku terlihat biru.

\section{Manfaat edukasi dalam tatalaksana asma}

Tidak ada keuntungan diperoleh dari obat asma terbaik yang ada/tersedia apabila tidak diketahui dan digunakan pasien dengan benar. Faktor pribadi sangat berperan untuk keberhasilan pengobatan. Morbiditas penyakit dapat ditekan dengan memberikan pengetahuan asma. ${ }^{18}$ Program KIE kepada pasien merupakan komponen penting untuk kesuksesan tata laksana asma. ${ }^{4,9}$ Program KIE optimis dapat mengendalikan asma, alergi dan biaya. Program KIE dapat mengurangi biaya pengobatan, kunjungan dokter ke rumah, juga mengurangi kunjungan ke Unit Gawat Darurat (UGD), dan perawatan rumah sakit. ${ }^{14,19}$

Garcia $\mathrm{dkk}^{20}$ melaporkan, pasien asma kronik dewasa mendapat program KIE efektif menekan morbiditas, meningkatkan fungsi paru dan mengurangi pemakaian steroid oral. Shah $\mathrm{dkk}^{21}$ mendapatkan, program aksi asma remaja secara klinik relevan meningkatkan kualitas hidup dan menekan morbiditas. Sosialisasi program KIE di sekolah berperan penting menurunkan beban asma pada remaja. Evans $\mathrm{dkk}^{22}$ menyatakan, program KIE pada klinik kesehatan mampu meningkatkan identifikasi (diagnosis) asma anak. Guevara $\mathrm{dkk}^{23}$ dalam suatu metaanalisis tentang efektifitas program KIE untuk manajemen asma pada anak dan remaja menyimpulkan 
penurunan absensi sekolah, peningkatan hari bermain, pengurangan kunjungan ke UGD dan gangguan tidur pada malam hari. Ringsberg $\mathrm{dkk}^{24}$ menyimpulkan pasien dengan gejala seperti asma diberikan program KIE asma dapat meningkatkan pengetahuan dan strategi menghadapi serangan.

Brown ${ }^{25}$ dalam suatu penelitian mendapatkan, edukasi yang diberikan kepada dokter anak, mampu menurunkan kunjungan dan perawatan darurat terhadap pasien risiko tinggi. Stevens $\mathrm{dkk}^{26}$ dalam suatu penelitian prospektif acak terkontrol dua pusat asma selama periode 13 bulan terhadap 200 anak balita dibekali program KIE kepada orang tuanya, tidak mendukung hipotesis tentang edukasi awal terhadap orang tua balita dengan asma dapat mengurangi morbiditas penyakit asma selama 12 bulan.

Program KIE juga bisa diberikan lewat media tertentu seperti media cetak, media elektronik dan program komputer. ${ }^{4,9,27}$ Krishna dkk ${ }^{28}$ melakukan penelitian pada 228 anak pasien asma menggunakan internet multimedia interaktif dalam program KIE meningkatkan pengetahuan tentang asma dan mengurangi gejala asma. McPherson $\mathrm{dkk}^{29}$ dalam suatu penelitian mendapatkan edukasi melalui program multi media adalah efektif dan menjadi alat yang populer dalam edukasi kesehatan untuk promosi keterampilan manajemen diri asma dalam ruang rawat anak. Penelitian Homer $\mathrm{dkk}^{30}$ menyimpulkan, KIE menggunakan program software tidak meningkatkan efektifitas lebih besar dibandingkan dengan KIE tertulis biasa.

\section{Ringkasan}

Program komunikasi, informasi dan edukasi (KIE) merupakan bagian tata laksana asma. Berbagai macam media bisa digunakan untuk melaksanakan program KIE. Dengan penerapan program KIE diharap dapat mengurangi kekambuhan asma, meningkatkan pengetahuan, mengurangi biaya pengobatan, dan meningkatkan kualitas hidup.

\section{Daftar pustaka}

1. Rahajoe N, Supriyatno B, Setyanto DB, penyunting. Pedoman Nasional Asma Anak. Jakarta: UKK Pulmonologi PP IDAI, 2004.

2. Liu AH, Spahn JD, Leung DYM. Childhood asthma.
Dalam: Behrman RE, Kliegman RM, Jenson HB, penyunting. Nelson textbook of pediatrics. Edisi ke-17. Philadelphia: Saunders; 2004.h.760-74.

3. UKK Pulmonologi PP Ikatan Dokter Anak Indonesia. Pedoman Nasional asma anak. Dalam: Respirologi Anak IV. Medan, 2003. h. 1-11.

4. Expert Panel Report 2. Guidelines for the diagnosis and management of asthma. NIH Publication, 1997;12346.

5. Expert Panel Report. Guidelines for the diagnosis and management of asthma. NIH Publication, 2002.

6. Wolf RL. Asthma. Dalam; Wolf RL. Essential pediatric allergy, asthma, and immunology. New York; McGraw Hill; 2004. h. 59-79.

7. Akib AAP. Asma pada anak. Sari Pediatri 2002;4:7882.

8. Boguniewicz M, Leung DYM. Allergic disorders. Dalam: Hay WW, Hayward AR, Levin MJ, Sondheimer JM penyunting. Current Pediatric Diagnosis \& Treatment. Edisi ke-16. New York: Lange Medical Book / McGraw Hill; 2003. h. 1051-61.

9. British Thoracic Society. British guideline on the management of asthma, a national clinical guideline. Revised edition April 2004.

10. Supriyatno B, Nataprawira HMD. Terapi inhalasi pada asma anak. Sari Pediatri 2002;4:67-73.

11. Lahdensuo A, Haahtela T, Herrala J. Randomised comparison of guided self management and traditional treatment of asthma over one year. Brit Med J 1996; 312 : 748-52.

12. D'Souza WJ, Slater T, Fox C dkk. Asthma morbidity 6 yrs after an effective asthma self-management programme in a Maori community. Eur Respir J 2000;15:464-69.

13. Schermer TR, Thoonen BP, v.d.Boom G. Randomized controlled economic evaluation of asthma selfmanagement in primary health care. AJRCCM 2002; 166:1062-72.

14. Anonymous. Prevention of Allergy and Allergic Asthma. WHO 2002;1-11.

15. Johansson SGO, Haahtela T. World allergy organization guidelines for prevention of allergy and allergic asthma. Int Arch Allergy Immunol 2004;135:83-92.

16. Guandelman S, Meade K, Benson M. Improving asthma outcomes and self- management behaviors of inner-city children. Arch Pediatr Adolesc 2002;156:114-20.

17. Wensley D, Silverman M. Peak flow monitoring for guided self-management in childhood asthma; a randomized controlled trial. AJRCCM 2004;170:60612. 
18. Partridge MR, Hill SR. Enhancing care for people with asthma: the role of communication, education, training and self-management. Eur Respir J 2000;16:333-48.

19. Moss MH, Mjaanes CM, Lemanske R. Asthma. Dalam: Rudolph CD, Rudolph AM penyunting. Rudolph's Pediatrics. Edisi ke-21. New York: McGraw Hill; 2003. h. 1950-63.

20. Garcý'a JMI, Tenorio MP, M.J. Giraldez MJC. Benefits at 3 yrs of an asthma education program coupled with regular reinforcement. Eur Respir J 2002;20:1095-01.

21. Shah S, Peat JK, Mazurski EJ dkk. controlled Effect of peer led programme for asthma education in adolescents: cluster randomised trial. Brit Med J 2001;322:1-5.

22. Evans D, Mellins R, Lobach K. Improving care for minority children with asthma: profesional education in public health clinics. Pediatrics 1997;99:157-64.

23. Guevara JP, Wolf FM, Grum CM, Clark NM. Effects of educational interventions for self management of asthma in children and adolescent: systemic review and meta-analysis. BMJ 2003;326:1-6.

24. Ringsberg KC, Lepp M, Finnström B. Experience by patients with asthma-like symptoms of a problembased learning health education programme. Fam Pract
2002;19:290-3.

25. Brown R, Bratton SL, Cabana MD, Kaciroti N, Clark NM. Physician asthma education program improves outcomes for children of low-income families. Chest 2004;126:369-74.

26. Stevens CA, Wesseldine LJ, Couriel JM. Parental education and guided self-management of asthma and wheezing in the pre-school child: a randomised controlled trial. Thorax 2002;57:39-44.

27. McPherson, Glazebrook C. Doble click for health: the role of multimedia in asthma education. Arch Dis Child 2001;85:447-9.

28. Krishna S, Francisco BD, Balas EA. Internet-enabled interactive multimedia asthma education program: a randomized trial. Pediatrics 2003;111:503-10.

29. McPherson AC, Glazebrook C, Forster D, James C, Smyth A. A randomized, controlled trial of an interactive educational computer package for children with asthma. Pediatrics 2006;117:1046-54

30. Homer C, Susskind O, Alpert HR. An evaluation of an innovative multimedia educational software program for asthma management: report of a randomized, controlled trial. Pediatrics 2000;106:210-15. 